\title{
Societal Power Shifts And Changing Social Identities In South Africa: Workplace Implications
}

\author{
Lize Booysen
}

Graduate School of Business Leadership, University of South Africa

\begin{abstract}
The enormous social, economic and political transformation South Africans have experienced especially over the past 12 years, since the systematic dismantling of apartheid in the era of social and economic reconstruction, has brought about numerous societal and social identity changes. Due to these changes in social identity, societal norms and power shifts, major changes are occurring in the workplace, and societal level identity crises and conflicts are increasingly spilling over into the workplace. This article unpacks these social identity changes and power shifts on the political, social, economic and management levels, by employing social identity theory, self-categorisation theory and embedded intergroup theory, and highlights some resultant workplace implications.
\end{abstract}

JEL M12

1

\section{South Africa in social identity crisis: Introduction and background}

In times of profound societal change and transformation, and in unstable societies where group boundaries and experiences frequently alter, changes also occur in how individuals perceive their group membership and how they assign themselves to specific social categories (Korostelina, 2003; Malanchuk, 2005). ${ }^{1}$ This phenomenon, where social identities are in flux and generalised categories are not yet redefined, can be called a crisis of identity (Ivanova, 2005; Bornman, 1999).

Andreeva (in Ivanova, 2005: 72) defines the crisis of social identity "as a state of consciousness in which most of the social categories by means of which an individual defines himself and his place in society, seem to have lost their boundaries and their value". This crisis is a sense of the loss of the rich, meaningful content of old internalised forms of societal identification and socialisation, and the search for new forms that meet the individual's basic need for meaning and for adaptation to changing social realities. A crisis of social identity is a change in mass consciousness (Bornman, 1999; Korostelina, 2003; Ivanova, 2005; Malanchuk, 2005; Wasserman, 2005).

The enormous political and social transformation South Africans have experienced over the past 12 years $^{3}$, since the systematic dismantling of apartheid in the era of social and economic reconstruction, is one such profound and radical change. Shifts in the dominance, status and power bases of the different groups have taken place (Booysen, 2006; Selby \& Sutherland, 2006).

In her research into ethnic identification in South Africa during transition, Bornman (1999) alludes to such social identity crises and argues that in periods of identity crises individuals have to explore, reflect on, re-evaluate or make decisions with regard to the identities that form part of their self-concepts. As a consequence of this re-evaluation of identity, changes are underway in South African society in the way people assign themselves to particular social categories and accept new values. Orthodox assumptions of identity are challenged, which cause breakdown of the "ideological glue" that keeps societies together.

This crisis of identity does not only occur when individuals face loss of status and opportunity in 
their newly assigned space in society (Ivanova, 2005; Korostelina, 2003; Malanchuk, 2005), but also in cases where they gain status and opportunity (Herriot \& Scott-Jackson). Furthermore, the sense of loss conceivably applies more to those groups previously in a dominant or privileged position (the Whites in apartheid South Africa) rather than those who see opportunity in the emerging shape of the future (the blacks in a post-apartheid South Africa) (Bornman, 1999; Thomas, 2004; Booysen, 2006).

From a systems perspective, it is important to note that open systems can only exist and survive through continuous interaction with the environment. Also, resilient societies are those whose actors can adapt to new conditions, so that a breakdown in "ideological glue" does not equate to social breakdown but rather to a shift in the organisation of the society in terms of identities and power relativities (Wheelan in Koortzen \& Wrogemann, 2003).

As a consequence of this social identity crisis, social identity and social self-awareness contradictions arise, both in individuals and in generations (Bornman, 1999; Gouws, 2005; Wasserman, 2005; Booysen, 2006).

\section{2}

\section{Social identity groups in South Africa}

Social identity groups can be defined for the purpose of this study as groups in which an individual's self-concept is derived from membership of the group (or category) along with the psychological value and emotional significance attached to that membership. Bornman (1999) points out that a positive or negative self-concept is often, and sometimes exclusively, defined by the status of the group to which the individual belongs in relation to that of other relevant groups in society.

Individuals have multiple simultaneous memberships of different social collectives, and thus have multiple identities with varying degrees of salience, given different contexts. Individuals thus unavoidably carry several layers of mental programming and self-categorisation within themselves, corresponding to the different groups to which they belong, at a cultural or subcultural level. For instance, a single individual can be influenced by a national culture, either of one country or several countries for those people who migrate during their lifetime; a regional, ethnic, religious and/or linguistic affiliation, as most nations are composed of culturally different subgroups; gender role expectations; generation characteristics; social class, which is associated with education, profession or occupation; an organisational or corporate culture, for those who are employed; sexual orientation; and personal ability (Hofstede, 1991; 1994; Ferdman, 1995; Malanchuck, 2006).

Ferdman (1995) refers to this constellation of cultural identities, the various different cultural levels or layers constructed by the individual, as a person's cultural identity structure, consisting of multiple identities overlaying one another. Cox and Finley (1995) refer to this structure as an individual's particular configuration of membership in cultural groups. In this study, this structure is called the individual's social identity structure or his/her repertoire of identities chosen from those available in a given society. An individual's social identity structure can be relatively stable, or can change and evolve.

South Africa is a complex and diverse society, with many available identities embedded in its societal fabric. Research shows that the most salient social identity groups in South Africa are race, gender, ethnicity and language 4 (Bornman, 1999; Cilliers \& May, 2002; Ngambi, 2002; Booysen \& Nkomo, 2005, 2006; Cilliers \& Smit, 2006). South African people are classified by population group. However, unlike in the past, membership of a racial group now tends to be based on self-perception and self-classification, not on a legal definition. ${ }^{5}$ Census 2001 classifies the population (Statistics South Africa, 2003) as follows: African black 79 per cent, coloured ${ }^{6} 8.9$ per cent, Asian or Indian 2.5 per cent and white 9.6 per cent. Black Africans constitute more than three-quarters of the total population. 53 per cent of South Africans are female and 47 per cent male, and South Africa has 31 different cultures.

To cater for South Africa's diverse peoples, the Constitution (South Africa, 1996) provides for 11 official languages, which co-vary with the 
different ethnic groups in South Africa. IsiZulu is the mother tongue of 23.8 per cent of the population, followed in incidence by isiXhosa (17.6 per cent), Afrikaans (13.3 per cent), Sepedi (9.4 per cent), English and Setswana (8.2 per cent each), Sesotho (7.9 per cent), Xitsonga (4.4 per cent), siSwati (2.7 per cent) and Tshivenda (2.3 per cent). The least spoken official indigenous language in South Africa is isiNdebele, which is spoken by only 1.6 per cent of the population. Recognising the historically diminished status and level of use in formal settings of the indigenous languages (other than English and Afrikaans), the Constitution expects the government to implement positive measures to elevate the status and advance the use of these languages. English is the unofficial official language of choice for business.

According to Census 2001, South Africa has eight religions and 25 denominations. Almost 80 per cent of South Africa's population follow the Christian faith. Other major religious groups are Hindus, Muslims and Jews. Approximately 6.8 million South Africans do not belong to any of these major religions, but regard themselves as traditionalists or of no specific religious affiliation. Freedom of worship is guaranteed by the Constitution and the official policy is one of non-interference in religious practices. According to the Constitution, no discrimination is allowed based on difference, whether of religion, age, sexual orientation or disability.

Members of social identity groups tend to seek out their own in religious organisations, schools, neighbourhoods and social clubs. The workplace may, of necessity or as in South Africa because of legislation, be the most heterogeneous institution within a community. In some cases the workplace may be the only instance where contact is made across the lines of different social identities (Byrne, 1971; Smith, Peterson, \& Schwartz, 2002; Nkomo \& Stewart, 2006). Therefore, the workplace makes an ideal context to study and address deep-seated social identity issues.

Due to changes in social identity, societal norms and power patterns in South Africa, major changes are also occurring in the workplace, and identity crises and conflicts in the broader society are increasingly spilling over into the workplace (Khoza, 1994; Mbigi, 1995; Manning, 1997; Bornman, 1999; Van der Westhuizen 1999; Cilliers \& May, 2002; Booysen, 2004; Lufthans, Van Wyk \& Walumbwa, 2004; Rautenbach, 2005; Van Gass, 2005; Cilliers \& Smit, 2006).

3

\section{Objectives of the study}

The objectives of this study are threefold: firstly, to give a brief overview of social identity and related theories; secondly, to give an overview of the power shifts that have taken place in South Africa at the political, economic, social and management levels over the past 12 years; and thirdly, to highlight possible workplace implications of changing social identities, due to these power shifts.

\section{4 \\ Social identity, self-categorisation and embedded intergroup theory}

Tajfel and Turner's (1979) social identity and self categorisation theory and Alderfer's (1987) embedded intergroup theory are both useful theoretical models to explain social identity group behaviour.

\subsection{Social identity and self-categorising theory}

Some of the most prominent intergroup theories explaining group identity effects on human behaviour have been social identity theory (SIT), put forward by Turner and Giles in 1981, and the extension on SIT, self-categorisation theory by Tajfel and Turner in 1979 (Nkomo \& Cox, 1996; Hogg \& Terry, 2000; Herriot \& Scott-Jackson, 2002; Abrams \& Hogg, 2004; Roccas \& Brewer, 2002; Ivanova, 2005;). SIT is a cognitive theory which holds that individuals tend to classify themselves and others into social categories and that these classifications have a significant effect on human interactions. SIT is concerned with both the psychological and sociological aspects of group behaviour and explains the psychological basis of group behaviour, group association and intergroup discrimination. It is composed of three elements: 
- Categorisation: Individuals often put others (and themselves) into categories. Labeling someone as an Afrikaner, a coloured or a rugby player for example are ways of saying other things about these people.

- Identification: Individuals also associate with certain groups (their in-groups), which serve to bolster their self esteem.

- Comparison: Individuals compare their groups with other groups, with a favourable bias toward the group to which they belong (positive discrimination), and competing with groups to which they do not belong.

The central idea of SIT is that social structure influences individuals' actions through the social psychological medium of social identity. In other words, the division of otherness and the attraction of sameness on the levels of ethnic, gender or class characteristics, do not persist because of inherent group characteristics, as pointed out by Abrams and Hogg (2004: 101), "...but because of the fact that those people identify with groups that exist in specific relation to one another."

Self-categorisation theory expands on the idea of category-based differentiation between people, to include the self. "This was a conceptual leap forward as it specified precisely how social categories caused people to perceive, think and behave as group members...Selfcategorisation renders certain attitudes and associated behaviors normative and causes people to behave in line with such norms" (Abrams \& Hogg, 2004: 103). In other words, these social categories provide a self-definition system in terms of the defining features of each category; the features of each category become the features of the self. Prototypes of categories develop, and members of each category come to assume that they all share (and are perceived to share by non-members) prototypical features. These category prototypes become stereotyped (Hogg \& Terry, 2000; Herriot \& Scott-Jackson, 2002). This process results in re-personalisation of both fellow adherents to a category and outgroup members, "with their personal identities submerged by their prototypical or stereotypical features" (Herriot \& Scott-Jackson, 2002: 255).
This also explains in-group favouritism and outgroup derogation.

Hogg and Terry (2000), Herriot and ScottJackson (2002) and Abrams and Hogg (2004) claim that self-categorisation theory also provides an explanation for changes in social identity, through the process of social categorisation of the self where the individual cognitively assimilates the self into the in-group prototype. Social categorisation of the self can be loosely associated with similar psychological processes like deindividuation or depersonalisation or rather re-personalisation ${ }^{7}$ Identity is in this model seen as fluid and deindividuation reflects not a loss but rather a change or reintegration of identity. This implies that, as attitudes about the self and perceptions of others about an individual's groups change, his/her social identity evolves/adapts in tandem. This also explains how the self is defined by group membership and how social cognitive processes associated with group membership-based self-definition result in characteristic group behaviour. Self-categorisation also explains how social identities can become more or less salient in different contexts, and in different social identity relativities.

\subsection{Social identity complexity}

Bornman (1999) and Roccas and Brewer (2002) claim that the process of social identity categorisation can also explain multiple social identities. Roccas and Brewer (2002) argue that research on the effect of multiple categorisation on perception clearly show that perceivers, more often than not, evaluate others on the basis of one dominant categorisation, and even ignore or inhibit alternative categorisation. This primary categorisation is then the most salient and all other group identities are subordinated. Others that share this salient social identity are classified as in-group members, and those who are without these characteristics are outgroup members. The most obvious factor that may affect social identity complexity is the actual complexity in the experienced social environment. Roccas and Brewer (2002: 96) contend that "social environments in which different bases for ingroup-outgroup distinctions 
are crosscutting rather than convergent confront the individual with knowledge about differences in meaning and composition of different social categorisations".

Bornman (1999) indicates that membership of ethnic or cultural groups is shown to be one of the major sources of social identification and identity formation. South African research by Bornman (1999) and Booysen and Nkomo (2005) finds that race is the most salient categorisation in the South African workplace. Alternative social identities, like gender, ethnicity and professional identity, seem to be embedded within the primary group identification of race as sources of intra-group variation, but are not extended to those outside that in-group. For instance, a black female manager, who assigns primacy to her race identity, regards all blacks as part of the in-group. Being a woman and manager describes what kind of black person she is, what makes her more or less similar to others in her in-group category or prototype. This results in the black woman manager feeling closer to other blacks than to other women or other managers. This dynamic is just more pronounced in contexts where some groups have dominance over others and where some groups are populated more or less prominantly by a specific group of people, as explained by the embedded-intergroup theory.

Roccas and Brewer (2002) also point out that, in complex societies where groups are under threat, individuals prefer clear group boundaries and tend to perceive their in-group as more homogeneous. Individuals in these circumstances tend to perceive the self as even more similar to the in-group and more different from the out-group, than under normal circumstances.

\subsection{Group embeddedness and dominance}

Two other aspects of social identity group dynamics that need some exploration are i) the effect of dominance between social identity groups and within social identity sub-groups, and ii) the influence of supra-systems on sub-systems. This will be explained by utilising Alderfer's (1986) embedded-intergroup theory.
Embedded-intergroup theory maintains an intergroup perspective and specifically highlights the effect of dominance between social identity groups and in- and out-group dynamics. Dominance refers to either dominance in number, hierarchy, status, power or access. Embedded-intergroup theory emphasises the importance of sub-groups within specific social identity groups. For instance, in examining the identity groups of black and white women, all these individuals share an identity group as women, but have separate cultural identity groups and different levels of dominance within society. They are two subgroups each with their respective status within one identity group. Their relative positions in society are thus mediated by their multiple group identities, their cultural constellation, as well as their membership groups' relative status in society. In the case of the black women manager example, race will be her primary identification, but in this instance gender will be her secondary identity categorisation, since the management group is male-dominated (Eagly \& Carli, 2003; Vecchio, 2004) and she is experienced and experiences herself as an out-group member in management.

Embedded-intergroup theory also explains the influence that supra-systems have on subsystems regarding the perceived dominance of specific identity groups. In dynamic parallel processes (mostly on an unconscious level) between the sub- and supra-systems reflected in their dynamics of dominance and subordinance, mutual reinforcing and conflicting pressures operate. "The outside affects the inside and the inside, in turn, affects the outside" (Alderfer, 1987: 210). To build on the example of black and white women' identity groups: black women's authority as individual managers (in the dominantly male manager sub-system) might be influenced negatively or compromised because of the lack of authority in the total system of firstly females (non-dominant female sub-system) and secondly blacks (nondominant black sub-system) due to the white male dominance of the management suprasystem. Thus as Alderfer, (1987: 215) points out, “The effects of one's own group's occupying a favourable position in a system may be muted 
by its being at a relative disadvantage in the supra-system".

\subsection{Social identity conflict}

Tension and conflict between diverse social identity groups are major disruptive factors in nearly every country in the world, and very real in South Africa (Rahim, 2001; Booysen, Nkomo \& Beaty, 2003). "Identity-driven conflicts are rooted in the articulation of, and the threats or frustrations to, people's collective need for dignity, recognition, safety, control, purpose, and efficacy" (Rothman, 1997:7).

Social identity conflicts can be distinguished from interpersonal conflicts by the nature of the causal attributions made by the disputants and by the amplification of the event to a larger collective (Simon \& Klandermans, 2001). When an individual and others attribute a conflict event to race, gender, religion, sexual preference, nationality or ethnicity and take sides based on their own race, gender, religion, sexual preference, nationality or ethnicity, this is a social identity conflict.

Social identity conflict is defined in this study as any discordant transaction that occurs between members of different social identity groups, which can be attributed to identity group membership, and which causes members of either group to feel unsafe, undervalued or disrespected. Social identity conflicts are rooted in threats to people's collective need for dignity, safety, recognition, control and purpose (Rothman, 1997: Haslam, 2001).

When social identity group conflicts occur in organisations, not only is work disrupted, but also group members experience substantial pain and distress that may only be remedied through significant and difficult organisational development interventions that affect changes in values, attitudes, norms and behaviours and workplace interaction.

\subsection{Conclusion}

This discussion of these theories has raised several important points. SIT and categorisation of the self have been shown to be relevant to explanations of:

i) a change in self-conceptualisation and the basis of perception of others in the group,

ii) in-group favouritism and bias and out-group derogation and prejudice, and resultant social identity conflict,

iii) the relative status or dominance of a group,

iv) the salience of primary and secondary identities, and the spillover of social identities into the workplace,

v) how individual behaviour can change (evolve) in tandem with group membership, and

vi) how individuals adapt to larger societal changes and changes in social group relativities and status, in other words, how individuals and social groups adapt to changing social realities during times of social identity crisis.

Embedded-intergroup theory has been shown to be relevant in explaining the effects of:

i) dominance between social identity groups and within social identity sub-groups, and

ii) the influence of supra-systems on subsystems.

All these theories explain identity dominance and salience as well as multiple identities. Although there are many categories of social identity and different social identity conflicts, the focus of this study is on changes and conflicts associated with race and gender, since these are the most pressing and intractable of the conflicts present in South African organisations (Ngambi, 2002; Booysen \& Nkomo, 2005; Booysen, 2006; Cilliers \& Smith, 2006,).

In the next section, the societal power shifts that have taken place in South Africa over the past 12 years will be discussed, and the implications of these changes on social identities will be highlighted. 


\section{5}

\section{Societal power shifts and social identity changes in South Africa since 1994}

Generally speaking, prior to 1994 power at all levels of society was held by white males, as the dominant group who wielded political, economic, managerial and social power. Almost by default, white women held some power as well, because they were associated with the then- dominant group. However, white women only held indirect power, due to their subordinate status as women in the dominant white race group. Power was thus almost exclusively in the white male domain, mainly due to race and sex discrimination and patriarchy; these men could almost be said to have held absolute power.

Figure 1 depicts the shifts in political, economical, managerial and social power that took place in the different broad race and gender groups after the 1994 democratic elections in South Africa.

\section{Figure 1}

Power shifts in South Africa since the first democratic elections

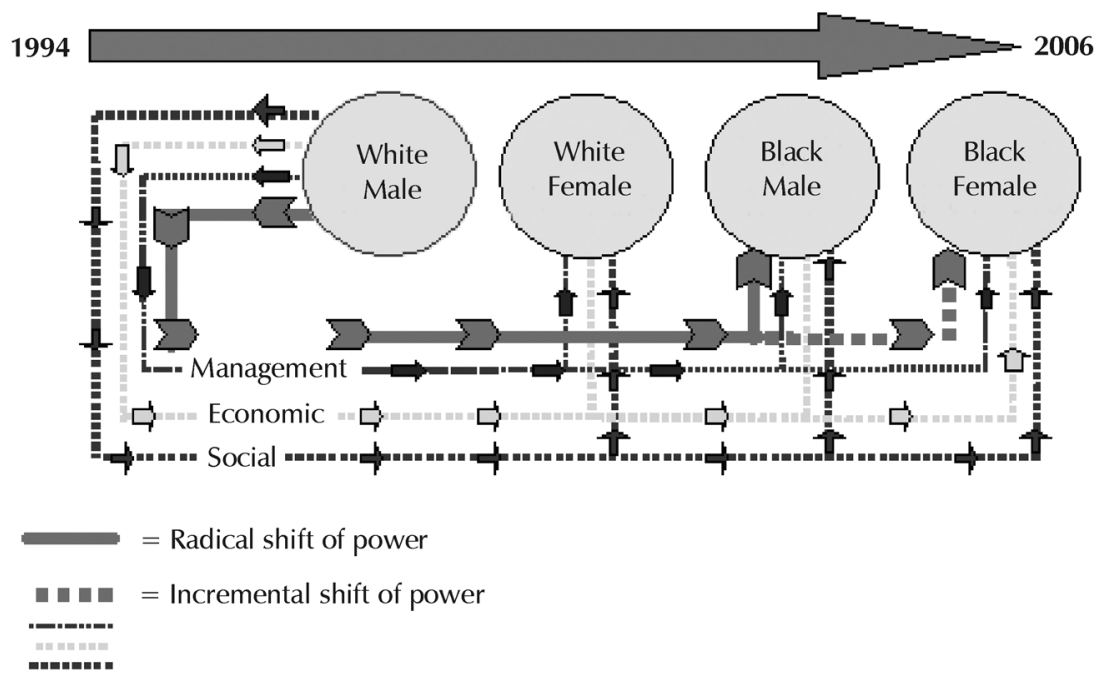

Weight of line or dashed line approximate gain or loss of power

The power shifts shown in Figure 1 will now be discussed. An overview will be given of the power shifts that have already happened and of those still in process in South Africa. It will be shown that political power shifted almost completely from white males to black males and to some extent to females, especially black females. It will be shown that social power moved from whites to blacks. It will furthermore be shown that even though shifts in management and economic power have already taken place, both power bases still reside with white males. Since this study focuses on the workplace, the implications of the power shifts and their impact on social identities, the emphasis will be on shifts in managerial power.

\subsection{Shifts in political power}

Political power was almost exclusively a white male domain prior to 1994 . Only six white women were elected to parliament over a period of 50 years during the reign of the National Party (Jaffer, 1998); this made up only 2.7 per cent, ranking South Africa 141 in the world with respect to per centage of women in parliament (Mathur-Helm, 2004; Booysen \& Nkomo, 2006). 
Literally overnight, on 27 April 1994, formal political power moved towards the black group, particularly towards black males. Black females also gained political power as the ANC instituted a quota rule of 30 per cent representation for women in parliament. In the Mandela government (1994-1999) women made up 27 per cent of parliamentarians, shifting South Africa to 15 in the world rankings by 1998. During President Thabo Mbeki's first term, following the 1999 elections, the quota was almost filled, as women made up 29.8 per cent of parliament. In 2006, during President Mbeki's second term, 33 per cent of parliamentarians are women, predominantly black women, and South Africa is ranked 11 in the world. The first South African Madam Deputy President was appointed on 22 June, 2005 (South African Government, 2006).

Even though it seems that black women currently have more formal political power than white women ever had under the apartheid regime, it can be argued that parliament is still too patriarchal, with males representing 67 per cent in parliament compared to their 47 per cent representation in the general population. This under representation of women is mainly due to gendered labour division (Naidoo, 1997; Paton, 1998; Booysen, 1999; Van der Westhuizen, 1999; Mathur-Helm, 2004; BWASA, 2006;). However, overall the changes in government and political power relations have brought an era of social and economic reconstruction.

According to social identity and selfcategorisation theory, predominant identities in national political contexts tend to be dominant and salient social identity categories for individuals (Malanchuck, 2006). In South Africa, in both the apartheid and now in the post-apartheid era, these dominant political identities are split along racial lines. The ANC was the dominant group for blacks in spite of its banned and underground status during apartheid. With the change in government in April 1994, the previously disadvantaged black majority group came into power and gained political dominance, through being the majority and having the status as the ruling party. The previously political dominant group, the white minority group, lost its political power, political dominance and status. This radical shift in political group dominance, with blacks now the dominant and whites the subordinate group, necessitates re-evaluation of existing prototypes of race, since the apartheid race categorisations now seem to have lost value, meaning and boundaries.

Regarding gender, nothing much has changed; as in the previous regime, males are still dominant and females subordinate in terms of power, number and status. It should be noted however that the ANC, unlike the previous regime, is striving towards gender equality, and some women, especially black women, have gained political power.

\subsection{Changes in legislation towards the empowerment of all}

On the journey towards transformation, a number of law reform and Affirmative Action (AA) measures have been initiated in South Africa, aiming to achieve greater social justice and equality and to redress past unfair discrimination and unearned privilege. South Africa's current economic transformation or Reconstruction and Development Programme (RDP), and the Growth, Employment and Redistribution (GEAR) strategy are part of the natural progression following the political transformation (Slabbert \& De Villiers, 2003). RDP and GEAR both aim to systematically re-engineer the political, social and economic landscape of South Africa.

Some of the first attempts at redressing the wrongs of the past were the Labour Relations Act of 1995, which took effect in 1996, the Constitution of South Africa of 1996, and the Basic Conditions of Employment Act of 1997. After these came the Employment Equity (EE) Act of 1999, and its anti-discrimination provisions, the Skills Development Act of 1998 and the Skills Development Levies Act of 1999. The intention of these last two acts is not only to shift the focus away from affirmative action appointments but also to promote recruitment, succession planning and development and training among persons in the designated groups (blacks and women) and to address the skills gap (Munetsi, 1999; Pillay, 1999; Helepi, 2000; 
Swanepoel, Erasmus, Van Wyk \& Schenk, 2003; Rautenbach; 2005).

These changes were followed by the establishment of the Broad-Based Black Economic Empowerment (BBBEE) Commission in 1999, and many subsequent strategies and policies set by the government and industry alike. The Black Economic Empowerment Act was implemented in 2003 and the Black Economic Empowerment Industry Charters with proposed quotas for black ownership and management followed. In 2004, the government sensed disparities and possible clashes between different industry charters and published a draft Code of Practice aimed at providing guidelines to the various branches of industry on how to set up their BBBEE schemes (Mulholland, 2004; Bouche \& Booysen, 2005; Rautenbach, 2005).

During 2007 the draft BBBEE codes of good practice will become law and will be at the top of every organisation's agenda. Every organisation in South Africa will require a BBBEE rating which will be in the public domain via the Department of Trade and Industry website (Wray, Sikhakane, Mokopanele \& Hamlyn, 2006).

\subsection{Economic power shifts since 1994}

A central objective of the RDP and GEAR is to de-racialise business ownership and control, through focused policies of BBBEE (BBBEE Commission Report, 2001). According to the BBBEE strategy document (Department of Trade and Industry, 2003: 15), BBBEE is defined as "an integrated and coherent socioeconomic process, that directly contributes to the economic transformation of South Africa, and brings about significant increases in the number of black people that manage, own and control the country's economy, as well as significant decreases in income inequalities." Subsidiary aims are to empower black people through mass creation of employment and their upward mobility in management and executive levels, through EE legislation.

Bouche and Booysen (2005) indicate that the first wave of BBBEE deals have for the most part come and gone. These deals have predominantly been completed by large corporations using speculative structures, many of which initially added no value, since the Johannesburg Stock Exchange (JSE) collapse of 1998 virtually dried up BBBEE deals (BBBEE Commission Report, 2001: 5). However, given the political, economic and social pressure placed on corporations by the government, not to mention the government's preferential procurement legislation and policies (South Africa, 2001), corporations have taken the lead in reviving BBBEE equity deals. Yet there are so few BBBEE players making corporate deals, which therefore predominantly involve only a privileged few black individuals with strong political influence, and at an ownership level only, that the BBBEE process has come to be seen as enrichment of a selected few as opposed to broad-based empowerment (Terreblanche, 2003; Rautenbach, 2005).

In spite of the general apathy regarding broadbased empowerment up to now, as Bouche and Booysen (2005) and Wray (2004) point out, a new wave of broad-based empowerment deals has started. These deals focus on empowering small and medium enterprises (SMEs). Since there is less capital and risk involved in deals at this level, and more pressure from clients, there is little doubt that the SME sector will be the engine for future economic growth in South Africa (Kemp, 2003; Khanyile, 2004).

\subsection{The effect of legislation on econo- mic power shifts and the workplace}

A Finance Week study on the progress of BBBEE, published April 2005, shows that, with regard to direct and indirect shareholding and control on the JSE, white South Africans effectively own and control just over 50 per cent of the JSE, compared to the 98 per cent they controlled in 1994 (Rautenbach, 2005).

A survey done by UNISA' s Bureau of Marketing Research (Rowen, 2000) shows a steep increase in the income level of African blacks and Indians, and a steady increase in the income of coloureds during the late 90s. Yet, despite BBBEE and the government's declared intentions, inequality has increased since 1994. According to Rautenbach (2005) and Alexander (2006), inequality has also increased 
significantly within the black community, due to the development of a strong black middle class, as well as the so-called black elite. This economic shift is sadly, but perhaps realistically, class-related.

Furthermore, an interesting shift is the jobhopping phenomenon presently experienced by African black managers due to the present high demand for and favourable job opportunities for African blacks. This is due to a skills-shortage, especially among blacks, in South Africa. Poaching of highly skilled blacks occurs often and companies pay a premium for high-calibre blacks, which leads to income disparities between blacks and whites (Bennet, 2001; Bhorat, 2001; Thomas, 2004; Van Rooyen, 2004).

Bhorat (2001), in an article explaining the employment trends in South Africa between 1993-1998, maintains that amongst the four races, white employees were the only group to see their absolute number of workers fall. $\mathrm{He}$ states that the reason for this decline does not lie in rising unemployment levels amongst whites, but instead can be found in lower participation rates amongst whites in this period. The two main explanations for this lower participation are growing emigration on the one hand and early retirement on the other. Bennet (2001) reports that a 2001 Human Capital Corporation study indicates that emigration (known popularly as the brain drain) accounts for 13 per cent of executive turnover in South Africa. The brain drain was still going strong in 2005, especially among holders of scarce skills, like engineers and medical doctors, across all race groups, due to better opportunities elsewhere; an estimated 1.6 million white South Africans are in the diaspora (Mulholland \& McKay, 2004; Theunissen, 2005). It can also be argued that this decrease in the absolute number of whites in the workplace suggests the voluntary and involuntary displacement of whites as a consequence of EE "space creation" drives and BBBEE exclusionary practices.

Although whites as a minority group wield a relatively large amount of economic power (buying power and quantity) on the JSE and in South Africa, there are numerous corporate and government initiatives that aim to redress this imbalance and improve the economic status and power of blacks. Even though blacks as a group now have much more economic power than ever before, they are by no means approaching economic parity with whites yet, and the road towards economic equality is still long and steep. However, there are already visible positive movements towards parity, and the effects of legislation are also already evident. BBBEE is expected to gain momentum in 2007 with the legislated codes of good practice, which will help the shift in economic power from whites to blacks. As a group, whites have already lost a substantial amount of economic power, and will in future lose even more. According to social identity and self categorisation theory, it is thus conceivable that this loss of power and status (also the loss of their dominant political status) will be experienced by whites as threatening and cause anxiety (Roccas \& Brewer, 2002; Ivanova, 2005). A young white male from a financial institution investigated in a previous study said, "Whites have no future, the white male career is on hold" (Booysen, 2004).

\subsection{Social power shifts since 1994}

Due to the shifts in political and economic power, a shift has also occurred in social power among the people of South Africa, and in the portrayal of different groups and individuals in these groups. Wasserman (2005) asserts that there is a definite general shift in the media debates away from Eurocentric or Western sentiments and portrayals towards a more Afro-centric approach, based on an "African Renaissance" philosophy that aims to promote new ways of thinking and re-construct postapartheid (and post-colonial) identities.

Social power used to be held almost exclusively by the white group prior to 1994. Now this power is distributed more evenly amongst all groups, though mostly concentrated in the black group, as can be seen in the present media coverage in South Africa. Apart from those people who are very important politically, the faces seen on television, in the news and on the society pages in the newspapers and magazines are predominantly black. The representation of various racial groups among South African performing artists and actors in advertisements, 
in the printed media and on billboards as well as voice artists tends to be much more in line with population figures. Quite recently, an exclusive networking and discussion group called the Native's Club was established for the African intellectual elite by the political advisor of President Thabo Mbeki, Titus Mafolo (Du Plessis, 2006).

It seems as if Africanism and African pride are occupying an increasingly important place in identity re-configuration, forming identities which are radically different from those of apartheid, where whites were seen as superior and blacks as inferior (LAnge, 2005; Wasserman, 2005). The social power is shifting from whites to blacks, and the social group dominant in status and access in South Africa now is the black group, not the white group anymore.

Questions have even been raised about the legitimacy of whites in South Africa. In their general council meeting discussion document published in June 2005, the ANC asked whether white Afrikaners are African. They suggested that it is time to answer the valid question about whether or not Afrikaners belong to Africa (Brown, 2005; Wasserman, 2005). It is suggested that white South Africans should be referred to as Eurokaners or Afropeers rather than as Africans, to reflect their European decent (L'Ange, 2005).

Wasserman (2005), furthermore, claims that identity politics and specifically a re-assertion of race can be seen as a particular feature of Mbeki's presidency. Wasserman analyses Mbeki's National Editor's Forum speech of July 2003, and shows strong tendencies to favour an essentialist African identity and to see some representations (African blacks) as more authentic than others (whites, coloureds and Indians). "African" suggests in this sense then an exclusionary category with an emphasis on past origins and associations with race rather than suggesting identity as an ongoing evolving process of categorisation.

This push to create an exclusive "African" group then means defining all other race groups as out-groups, with inclusive privilege and outgroup derogation. It can be argued, in fact, that this is simply a new form of oppression and exclusion replacing the old apartheid system of oppression and exclusion. Everything used to belong to the whites, now everything belongs to the African blacks - minority groups rights are still not honoured (Brown, 2005; Booysen, 2006). It thus seems that race group categorisations are entrenched in a manner which cements old identities and only superficially re-arranges the positions of dominance in the South African society.

The next section investigates the effects of these power shifts and social identity changes in the workplace, with specific focus on management levels.

\subsection{Management power shifts since 1994}

In 1994, management power resided almost exclusively with white males. White males held more than 80 per cent of management positions (Central Statistical Service, 1995a, 1995b). Moreover, Rautenbach (2005) points out that a London Business School study showed that in 1990, black management in white firms was estimated to be approximately 4 per cent, although blacks made up over 85 per cent of the population.

Thomas (2004), Horwitz, Jain and Mbabane (2005), Booysen and Nkomo (2006) and Selby and Sutherland (2006) all point out that only limited progress has been made in achieving employment equity since the legislation was enacted in 1996. A factor perhaps could be that slow job growth has "frozen" the job market. Faster growth would pull more people into positions.

A comparison between the 2001 and 2005 Commission for EE reports (Department of Labour, 2002, 2005, 2006) shows that there is slow progress in the implementation of the Employment Equity Act at management level. It appears, however, that momentum is building, as demonstrated in the increase of employment of blacks ( 5.25 per cent) in general and females in top and senior management positions (5.25 per cent). However, there is a drop in the representation of blacks (-11.5 per cent) and only a slight increase in that of females ( 0,2 per cent) from 2001 to 2005 , with a decrease in the representation of both African 
and coloured females at the professional and middle management level of employment. This is worrying in terms of $\mathrm{EE}$, since the professional and middle management level is considered the "feeder" to senior and top management positions. If this decrease continues it will not be possible to fill these positions with black males and females. Furthermore, the benefits of BBBEE have to a large extent not accrued to black females, who continue to be poorly represented in top management with a growth of only 1.3 per cent from 2001 to 2005 and in senior management with a growth of only 1.1 per cent from 2001 to 2005 (Department of Labour, 2006: 55-58).

In its latest annual report, the Commission for EE reports on the period July 2005 to April 2006, and gives telling evidence of the (in)effectiveness of the workplace transformation legislation (Department of Labour, 2006).

Table 1 provides a breakdown of the total number of employees in the categories of top management, senior management, and professionals and middle management.

\section{Table 1}

Total number of employees in management level by race and gender

\begin{tabular}{|l|r|r|r|r|r|r|r|r|}
\hline \multirow{2}{*}{$\begin{array}{l}\text { Occupational } \\
\text { levels }\end{array}$} & \multicolumn{4}{|c|}{ Male } & \multicolumn{4}{c|}{ Female } \\
\cline { 2 - 10 } & black & coloured & Indian & white & black & coloured & \multicolumn{1}{|c|}{ Indian } & white \\
\hline Top management & $13.2 \%$ & $2.7 \%$ & $4.7 \%$ & $62.7 \%$ & $4.7 \%$ & $1.0 \%$ & $0.9 \%$ & $9.9 \%$ \\
\hline $\begin{array}{l}\text { Senior } \\
\text { management }\end{array}$ & $10.3 \%$ & $4.3 \%$ & $5.4 \%$ & $56.3 \%$ & $4.2 \%$ & $1.7 \%$ & $1.6 \%$ & $16.1 \%$ \\
\hline $\begin{array}{l}\text { Professions } \\
\text { and middle } \\
\text { management }\end{array}$ & $14.6 \%$ & $5.9 \%$ & $5.3 \%$ & $41.5 \%$ & $6.9 \%$ & $3.4 \%$ & $2.6 \%$ & $19.8 \%$ \\
\hline
\end{tabular}

Source: Adapted from Department of Labour (2006: 22)

From Table 1 it is evident that whites and males, and specifically white males, still dominate top management, senior management and professional and middle management positions. The top management level is made up, in descending order, of 62.7 per cent white males, 13,2 per cent African black males, 9.9 per cent white females, 4.7 per cent Indian males, 4.7 per cent African black females, 2.7 per cent coloured males, 1.0 per cent coloured females and 0.9 per cent Indian females.

The senior management level is made up, in descending order of 56.3 per cent white males, 16.1 per cent white females 10,3 per cent African black males, 5.4 per cent Indian males, 4.3 per cent coloured males, 4.2 per cent African black females, 1.7 per cent coloured females and 1.6 per cent Indian females.

The professional and middle management level is made up, also in descending order, of
41.5 per cent white males, 19.8 per cent white females 14,6 per cent African black males, 6.9 per cent African black females, 5.9 per cent coloured males, 5.3 per cent Indian males, 3.4 per cent coloured females and 2.6 per cent Indian females.

From these figures, it seems that the white group, particularly white males, still dominates management positions (53 per cent), proportionally and absolutely. White females, however, are not the second largest group anymore (Booysen, 2006), since African black males (22 per cent) now form the second largest group, leaving white females to make up the third largest group with 15 per cent. African black women (10 per cent) are the most underrepresented at all levels of management.

The 2004 Census of South African Women in Corporate Leadership, published by the Business Women's Association of South Africa 
in association with Catalyst (USA), surveyed the women on boards of directors and in executive management of public companies listed on the JSE as on 30 September, 2004 (BWASA, 2005). The results give a similar picture regarding gender and show that women constitute only 19.8 per cent of all executive managers and only 10.7 per cent of all directors. Of the 19.8 per cent of female executive managers, 83.8 per cent are white women and 16.3 per cent are black women (African black 8.3 per cent, coloured 2.2 per cent and Indian 5.8 per cent). The 10.7 per cent of female directors is made up of 56.5 per cent black women (African black 48.1 per cent, coloured 4.9 per cent and Indian 3.6 per cent) and 43.8 per cent white women. The 2005 Census (BWASA, 2006) shows some minor shifts, with the greatest area of improvement apparently lying in the steady advancement of women at directorship level. The first study, done in 2003, showed that only 7.1 per cent of all directors were women, the 2004 study shows 10.7 per cent, and the latest census shows that 11.5 per cent of all directors are women.

Yet, one of BWASA's (2006) conclusions is that, "although the number of women executive managers has increased, indications are that, in relative terms, women are losing ground in this category. The latest results show that...16.8 per cent of executive management positions are held by women, compared to 19.8 per cent for the previous year. The decline is significant given the substantial increase in the overall number of executive management positions (from 5558 in the 2005 Census to 7890 in the 2006 study)." In terms of race, it seems as if there is a slow movement towards a more representative profile, but there is still a long way to go. In 2005 and 2006, of the 362 directorships held by women, 48.1 per cent were held by black women. This is in sharp contrast to the race split in executive management positions, which shows that 77 per cent (83.3 per cent in 2004) of all women executive managers in South Africa are white.

It is evident that, despite various regulations put in place since 1994, the white group, particularly white males, still dominate management positions. Interestingly, white females are not the second largest group anymore, a place taken by black males, leaving white females as the third largest group. Black women are the most underrepresented, at all levels of management. It thus seems that, although there is now formal legislated equality in the South African workplace, it will take some time before there is substantive equality, because of societal discrimination and the residual effects of past discrimination. This discussion clearly indicates that, while progress has been made, race and gender gaps still exist at the decision-making level of management in South African organisations.

\section{6}

\section{Workplace implications of social identity changes and power shifts in South Africa}

Based on the theories discussed and the power shifts explored so far, the following themes can be identified in current social life in South Africa.

\subsection{Dominant national social identities spill over into the workplace}

All individuals have multiple identities, which differ in their centrality or dominance and salience, given different contexts. Furthermore, individuals more often than not are evaluated and evaluate others on the basis of one dominant categorisation, and even ignore or inhibit alternative categorisation. Other people who share this salient social identity are classified as in-group members, sharing the in-group privilege and bias, while those who do not share the identity are out-group members, sharing out-group discrimination and prejudice. In societies or situations where a social identity is repeatedly salient, as for instance race in the South African situation, a prototype of that category is developed, and members of that category come to assume that they all share (and are perceived to share, by non-members of that category) prototypical features. This category prototype becomes stereotyped, and tends to exclude others.

In line with Malanchucks' (2006) finding that the predominant identities in national political 
contexts become the dominant and salient social identity categories for individuals, Bornman (1999), Cilliers and May (2002), Ngambi (2003), Booysen and Nkomo (2004, 2005, 2006) and Cilliers and Smit (2006) clearly show that the most salient social identity in the South African workplace is race, with gender in second place. Prototypical perceptions of non-group and group members are clearly illustrated in the following quotes from Booysen (2006):

- Black comments about whites' perception of blacks: "[They act as if] you have been accepted in an AA position and therefore you are not totally competent to handle the responsibilities of the job"; in other words, whites perceive blacks as incapable, even if they have skills, experience, degrees etc. This perception must be broken down.

- White comments about blacks; "PDI's (previously disadvantaged individuals) get appointed and promoted above their ability - then we have to report to them, while doing the work."

Cilliers and Smit (2006) find an interesing shift in race as the most dominant social identity categorisation, from the position where black participants are united in their hostility towards white participants towards a gender split among blacks, where black females express their hostilities towards black males. Cilliers and Smit argue that a new social identity dynamic is emerging, with "males, black and white, becoming more united in the presence of the black females' power...Because black females are taking on such powerful roles in organisations, the racial divide between males is becoming smaller as a result of their mutual experience of loss of social power" (2006:13-14). This dynamic might also be as a consequence of the powerful roles black women occupy in the government and business (Booysen \& Nkomo, 2006).

\subsection{Social identity conflict can be expected in South African workplace}

The accentuation of group differences and similarities and the dynamics between in-group and out-group can cause social identity conflict in the workplace (Haslam, 2001; Rahim, 2001). Conflict can be expected around strong and negative stereotypes about other groups, bias, prejudice, blaming, generalisations and projection of emotions, like anger and frustration. Polarisation of different social identity groups becomes more pronounced, and social identity diversity in team members more likely to result in conflict than in innovation (Cilliers \& May, 2002; Booysen \& Nkomo, 2004, 2005; Cilliers \& Smit, 2006).

In their research on social identity conflict in South African organisations, Booysen and Nkomo (2005) refer to a number of incidents where simple contact between various groups evolved quickly into social identity conflict, often via very mundane events. For example, a conflict situation around the air conditioner temperature in the room spilled over into social identity conflict and racism and the following comment was made by a black person towards a white person: "When I look at you, I think of how my grandfather suffered." With Cilliers and Smit (2006) it can be said that it would be naïve to think that social identity issues will ever completely disappear from the South African organisational discourse.

\subsection{Organisational sub-systems influence the effect of government supra-systems}

The significant power shifts that have already taken place are still in process and have not yet been played out fully. Whites, as a minority which previously held absolute power, still have the most economic and management power. Moreover, even though the blacks have power in the political supra-systems, they do not yet have much power in management or organisations. This is illustrated not only in the numbers discussed above, but also in the change resistant organisational cultures, as illustrated by a black male quotation in Booysen (2006): "The current culture is white, we don't like golf and having wine at a restaurant, because we do not enjoy it - nor have the money. This is not black culture." The effect is that organisational cultures are experienced as exclusionary, and pose a real barrier to retaining black talent (Thomas, 2004). 
The effects of an individual's dominance in one group may be muted by his/her relative subordinance in another group; as mentioned above, for example, a black women's authority as individual manager in the dominant manager sub-system can be compromised because of her lack of authority in the management suprasystem, dominated by white males. This is illustrated by a black female manager's quote in Booysen (2006): "The insecurity felt here for black women is perpetuated by the lack of follow-up and coaching in a predominantly white male environment."

The inverse is also true. Even though the supra-structure of the government's laws favours black women most, relative to any other group in South Africa at present, the social dynamics between the identity of black female managers and that of organisational and management groups favouring whites and males, mute the relative advantage of black women. As one senior black female proclaimes, "Stop patronising black generic females by having correct policies in place but still implementing unfair practices in a patriarchal society, e.g. 'You can have the title but you are not good enough to take the extra responsibility or handle the authority"' (Booysen, 2006).

\subsection{Strong social identities supersede organisational culture}

In line with Herriot and Scott-Jackson (2002), it can be argued that to the extent that social identities are salient for employees in the work situation, these identities will maintain the beliefs, values and norms associated with their identity at the expense of those organisational beliefs, values and norms which are incompatible. This means that the strength of the salient social identity will supersede that of the organisational culture. The following quote in Booysen and Nkomo (2005) by a white female in an organisation where inclusiveness and diversity are valued, illustrates this: "I think it is mostly when we just socialise and they start socialising in their mother tongue or they start talking about something that I don't want, or ordering food that I don't eat, I feel excluded. That's when I think, OK, fine, I'm not totally part of them." This is also an example of pronounced polarisation of in-group/out-group identification, prototypical behaviour and outgroup exclusionary behaviour. Similar incidents are also discussed where Afrikaans is used in an exclusionary way.

The next quote in Booysen and Nkomo (2004) by a black woman also illustrates the strength of the salient social identity which supersedes that of the organisational culture. It also illustrates how stereotypical social categorisations of race, which have already lost value and boundaries in most organisations, still persist: "If it is dirty and it is dirty around you, you know, take the dishcloth and wipe, but now because I think maybe it had to do with South Africa as a whole, you know, if you are a white lady you've got a black domestic worker at home and then you come to work, then you think all the black women are your domestic workers, they should clean up after you. We [black women] don't think so, you know, it is not the case, so I think maybe that type of mentality."

\subsection{Change and transformation are perceived differently by the different social identity groups}

Changes and transformation in the workplace are perceived either as too slow or too fast, depending through which cultural lens they are looked at, as illustrated by a white male manager in Booysen (2004): “The changes in our country [are] just too fast for the whites and not fast enough for the blacks."

There are also feelings of entitlement and threat, as noted by a coloured male in Booysen and Nkomo (2005): "Depends on from which group you are coming. One group feels entitled as if they have a licence, another group feels threatened. Both groups are negative." Contradictory perceptions around the changes and transformation thus exist.

Firstly, some social identity groups feel left out. While the most salient social identity issues are between whites and African blacks, the coloured and Indian groups also experience feelings of being left out (Ngambi, 2002; Booysen, 2006). Affirmative action initiatives are perceived as African black empowerment 
measures, not really beneficial to coloureds and Indians/Asians, who have a lesser claim to previous disadvantage than African blacks. There is a general perception amongst the coloureds in South Africa that in the previous dispensation they were not white enough, and in the current dispensation they are not black enough, as illustrated by an Indian female manager quoted in Booysen (2006): "When it was white government, of course, it was seen that Indians were favoured because they weren't too black, and now that it's black government we are still not being favoured, but if I apply for a position in affirmative action, I am not going to get it, because I am not black."

Whites as a social identity group feel threatened: Social identity groups under threat prefer clear boundaries, protect themselves, and perceive their in-group as more homogeneous (Roccas \& Brewer, 2002; Ivanova, 2005). Even though whites still have the most management and economic power they do feel threatened. White people as a group are showing high levels of social identity anxiety, due to their loss of power and the changes in South Africa (Ngambi, 2002). This affects white males more obviously, since they were in the most powerful position and had absolute power prior to the political change.

High levels of job insecurity are experienced by white males, who see a real lack of future promotional opportunities; they do not feel valued, as can be seen from the following quotes by white males in Booysen (2004): "No job security for white males" and "Lack of job security and the promotions situation make us feel not valued." White males experience feelings of de-motivation, as other quotes from Booysen suggest: "White males are de-motivated - they just perform to maintain their jobs - no initiative, because it is not going to get rewarded, and it is soul damaging to hear you can only grow so far and not more, and want more structure... if I know where my career was going, I will stay - if I know what my career prospects are, I do not know how far can I go."

White males feel threatened and experience an employment equity ceiling: "All positions and promotions are filled by people of colour, there is very little opportunity to develop, small quotas for white males", and "Limited career growth for white males and also a ceiling".

In-group protection by white females can also be clearly seen in the following quote by a black female: "Black women under-perform, because the white women refuse to train a black person and support them through the process. It is a challenge and becomes a vicious circle", and also in the following claim by a white male senior manager: "It is not exchanging the whites with the blacks. It is about changing mindsets - about changing the minds of the blacks to realise whites have a role to play" (Booysen \& Nkomo, 2005)

\section{7}

\section{Concluding thoughts}

As a result of radical societal power shifts in South Africa, all the different population groups are undergoing social identity re-categorisation and a profound re-personalisation process. New prototypes are evolving in tandem with changed social realities. The loss of identity and of internalised learned boundaries and prototypes are severely felt, not only in those groups that are gradually losing power but also in the groups that have gained most power. For instance, black females must paradoxically now contend with a new dynamic, where black and white males unite forces against her newly gained power position (Cilliers \& Smit, 2006). A whole new social identity dynamic is already emerging.

For the group that had absolute power a little more than a decade ago, the white male, the perception is one of an increasing loss of future expectation, opportunity and resulting sense of disempowerment, which leads to great anxiety. The current reality however remains that most power is still held by the white male group.

Presently, societal changes are still dictated by or bound within primarily racial categories, due to the polarisation of South African society. The question remains as to how South Africans can un-think old categories of citizenship and redefine themselves as a nation, in order to move beyond racial categorisation and their own political bondage. New social identities could conceivably be constructed, from categories coupled to professional identities, work 
identities, socio-economic status or other new social identities rooted in some factor other than race.

Although the pace of change seems slow, South Africa has already undergone so much transformation that fundamental changes have already occurred. It can be concluded with Van Gass (2005) that "we have travelled so far on our transformation journey that we are another nation" however it can be added "we have so much learning and un-learning to do that the journey has but just begun".

1 I thank Stella Nkomo, Karin Hougaard and the two anonymous SAJEMS reviewers for helpful and most valuable comments on this article.

2 It can even be argued that these changes already started in the early eighties with the labour reforms based on the Wiehahn reports (Horwitz, Jain \& Mbabane, 2005).

3 For instance, the most salient social identity groups the author identifies with are white, female and Afrikaans. Also, take note that this specific status might have led to some bias in interpretation in this study.

4 It might be argued that the legal definition of the different race categories is still preserved by the EE legislation for purposes of positive and fair discrimination.

5 "Coloureds" are the descendants of black and Indian slaves, the indigenous Khoisan people and white settlers in South Africa.

6 To differ from Hogg and Terry (2000) and Herriot \& Scott-Jackson (2002), social categorisation of the self can rather be seen as a re-personalisation than a depersonalisation process. Depersonalisation refesr to a psychopathological state in which the self and/or the context is experienced as unreal and the self is being alienated (DSM - 111$\mathrm{R}$, 1987). Re-personalisation, in this sense refers to a re-integration of the self in larger social and group identities, and not an alienated self.

\section{References}

1 ABRAMS, D. \& HOGG, M.A. (2004) "Metatheory: Lessons from social identity research," Personality and Social Psychology Review, 8(2): 98-106.

2 ALDERFER, C. (1986) "An intergroup perspective on group dynamics," in Jorch, J. (ed.) Handbook of Organizational Behavior: 190 - 222, Prentice Hall: Englewood Cliffs, N.J.

3 ALEXANDER, M. (2006) "Black economic empowerment," South Africa Info, http://www. southafrica.info (Accessed 16 May 2006).

4 BENNET, J. (2001) "Companies bleeding skilled blacks at a rapid rate," Sunday Times, 25 March: 5.

5 BHORAT, H. (2001) "Explaining employment trends in South Africa: 1993-1998," New Agenda South African Journal of Social and Economic Policy, 4: 21-38.

6 BLACK ECONOMIC EMPOWERMENT COMMISSION (2001) Black Economic Empowerment Commission Report, Skotaville Press: Johannesburg.

7 BOOYSEN, L. (1999) "A review of challenges facing black and white women managers in South Africa," Southern African Business Review, 13(2): 15-26.

8 BOOYSEN, L. (2004) Review of Org X Retail Employment Equity and Retention Strategy, UNISA: Midrand.

9 BOOYSEN, L. (2006) "Social identity changes: Challenges facing leadership," in April, K \& Shockley, M. (eds.) Diversity in Africa: The Coming of Age of a Continent: 127-156, Basingstoke, Palgrave Macmillan: Hampshire.

10 BOOYSEN, L. \& NKOMO, S.M. (2004) Org X: Leadership across Difference Report, Centre for Creative Leadership in collaboration with the Graduate School for Business Leadership, UNISA: Midrand.

11 BOOYSEN, L. \& NKOMO, S.M. (2005) Org Y: Leadership across Difference Report, Centre for Creative Leadership in collaboration with the Graduate School for Business Leadership, UNISA: Midrand.

12 BOOYSEN, L. \& NKOMO, S.M. (2006) "Think manager - Think female," International Journal of Interdisciplinary Social Sciences, 2(1): 24-36.

13 BOOYSEN, L.; NKOMO, S. \& BEATY, D. (2002) "Breaking through the numbers game: High impact diversity," Management Today, 18(9): 22-24.

14 BOOYSEN, L.; NKOMO, S. \& BEATY, D. (2003) "A best practice model for building a valuing diversity culture," Management Today, 19(1): 33-36. 
15 BORNMAN, E. (1999) "Predictors of ethnic identification in a transitionary South Africa," South African Journal of Psychology, 29(2): 62-72.

16 BOUCHE, J \& BOOYSEN, L. (2005) "Facing the unknown: Introducing BEE into SMMEs," Management Today, 21(4): 46- 47.

17 BROWN, K. (2005) "Ruling party ponders identity in a divided nation," Business Day, May: 17.

18 BWASA (Business Women's Association South Africa, Catalyst USA) (2005) South African Women in Corporate Leadership: Census 2004, Nedbank Press: Sandton.

19 BWASA (Business Women's Association South Africa, Catalyst USA) (2006) South African Women in Corporate Leadership: Census 2005, Nedbank Press: Sandton.

20 BYRNE, D. (1971) The Attraction Paradigm, Academic: New York.

21 CENTRAL STATISTICAL SERVICE. (1995a) October Household Survey 1994, CSS: Pretoria.

22 CENTRAL STATISTICAL SERVICE. (1995b) Statistical Release PO317, CSS: Pretoria.

23 CILLIERS, F. \& MAY, M. (2002) "South African diversity dynamics: Reporting on the 2000 Robben Island Diversity Experience, a group relations event," South African Journal of Labour Relations, 26(3): 42-68.

24 CILLIERS, F. \& SMIT, B. (2006) "A systems psychodynamic interpretation of South African diversity dynamics: A comparative study," South African Journal of Labour Relations, 30(2): 5-18.

25 COX, T.H. Jr \& FINLEY, J.A. (1995) "An analysis of work specialisation and organisation level as dimensions of workforce diversity", in Chemers, M.M., Oskamp, S. \& Costanzo, M.A. (eds.) Diversity in Organisations: New Perspectives for a Changing Workplace: 62-90. Sage: London.

26 DEPARTMENT OF LABOUR (2002) Annual Report - Commission for Employment Equity 20012002, Government Printer: Pretoria.

27 DEPARTMENT OF LABOUR (2003) Annual Report - Commission for Employment Equity 2002 - 2003, Government Printer: Pretoria.

28 DEPARTMENT OF LABOUR (2006) Annual Report - Commission for Employment Equity 2005 - 2006, Government Printer: Pretoria.

29 DEPARTMENT OF TRADE AND INDUSTRY (2003) Broad-Based Black Economic Empowerment Act, Government Printers: Pretoria.

30 DIAGNOSTIC AND MANUAL AMERICAN PSYCHIATRIC ASSOCIATION (1987) Diagnostic and Statistical Manual of Mental Disorders (3rd ed. Revised). (1987). Washington, DC. USA.
31 DU PLESSIS, T. (2006) "'n Broederbond net vir swartes," Beeld, 24 May: 4.

32 EAGLY, A.H. \& CARLI, L.L. (2003) "The female leadership advantage: An evaluation of the evidence," The Leadership Quarterly, 14: 807-834.

33 FERDMAN, B.M. (1995) "Cultural identity and diversity in organisations: Bridging the gap between group differences and individual uniqueness," in Chemers, M.M., Oskamp, S. \& Costanzo, M.A. (eds.) Diversity in Organisations: New Perspectives for a Changing Workplace: 37-61. Sage: London.

34 GOUWS, A. (ed.) (2005) (Un)thinking Citizenship. Feminists Debates in Contemporary South Africa, Juta: Cape Town.

35 HASLAM, S.A. (2001) Psychology in Organisations: The Social Identity Approach, Sage: London.

36 HELEPI, G. (2000) "Moulding strategic affirmative training and development," People Dynamics, 18(3): 34-36.

37 HERRIOT, P. \& SCOTT-JACKSON, W. (2002) "Globalization, social identities and employment," British Journal of Management, 13: 249-257.

38 HOFSTEDE, G. (1991) Cultures and Organisations: Software of the Mind, McGraw-Hill International: London.

39 HOFSTEDE, G. (1994) Uncommon Sense about Organisations: Cases, Studies and Field Observations, Sage: London.

40 HOGG, M.A. \& TERRY, D.J. (2000) "Social identity and self-categorization processes in organizational contexts," Academy of Management Review, 25(1): 121-140.

41 HORWITZ, F.; JAIN, H. \& MBABANE, L. (2005) "Trade union consultation by employers under employment equity legislation," Journal of Labour Relations, 29(2-4): 4-32.

42 IVANOVA, N.L. (2005) "Social identity under various socio-cultural conditions," Russian Education and Society, 47(11): 71-87.

43 JAFFER, Z. (1998) "Women still on a road to nowhere," Sunday Times, May 16: 4.

44 KEMP, S. (2003) "SMEs needed," Mboweni Moneyweb, 9 October, http://www.moneyweb.co.za. (Accessed 3 March 2004).

45 KHAYILE, T. (2004) "Empowerment must bring clear value," Business Day, 16 September: 5.

46 KHOZA, R. (1994) “ The need for an Afrocentric management approach: A South African-based management approach," in Christie, P.; Lessem, R. \& Mbigi, L. (eds.) African Management: Philosophies, Concepts and Applications: 117-124. Sigma Press: Pretoria. 
47 KHOSA, M. (2001), 'The empowerment challenge: Not yet uhuru?', in M. Khosa, Empowerment through Economic Transformation: 441-448, Pretoria: HSRC.

48 KOORTZEN, P. \& WROGEMAN, G. (2003) "Intergroup dynamics in a business consulting organisation," South African Journal of Labour Relations, 27(3\&4): 79-105.

49 KOROSTELINA, C. (2003) "The multiethnic state-building dilemma: National and ethnic minorities' identities in the Crimea," National Identities, 5(2): 142-159.

50 L'ANGE, G. (2005) The White Africans from Colonisation to Liberation, Jonathan Ball: Johannesburg \& Cape Town.

51 LUTHANS, F.; VAN WYK, R. \& WALUMBA, F.O. (2004) "Recognition and development of hope for South African organization leaders," The Leadership \& Organization Development Journal, 25(6): 512-527.

52 MALANCHUK, O. (2005) "Social identification versus regionalism in contemporary Ukriane," Nationalities Papers, 33(3): 345-368.

53 MANNING, T. (1997) Radical Strategy: How South African Companies can Win against Global Competition, Zebra Press: Sandton.

54 MATHUR-HELM, B. (2004) "Equal opportunity and affirmative action for South African women: A benefit or barrier?" Women in Management Review, 20(1): 56-71.

55 MBIGI, L. (1995). "The roots of ubuntu in business: A definitive perspective," in Mbigi, L. \& Maree, J. (eds.) Ubuntu: The Spirit of African Transformation Management: 77-92. Knowledge Resources: Johannesburg.

56 MULHOLLAND, S. (2004) "Hijacking affirmative action - Nothing sacred: openers," Finance Week, 2 August: 17.

57 MULHOLLAND, S. \& MCKAY, D. (2004) "Black mark, Mbeki: nothing sacred," Finance Week, 24 May: 15.

58 MUNETSI, W. (1999) "Affirmative action: A simplistic view," People Dynamics, 17(1): 36-37.

59 NAIDOO, G. (1997) "Empowerment of women in the corporate world," People Dynamics, 15(5): 30-35.

60 NGAMBI, H. 2002. "The role of emotional intelligence in transforming South African organisation," Proceedings of the International and Management Sciences Conference: 221-231. Vanderbijlpark.

61 NKOMO, S.M. \& COX, T. Jr. (1996) "Diverse identities in organizations," in Clegg, S.; Nord,
W.R. \& Hardy, C. (eds.) Handbook of Organization Studies: 339-356, Sage: London.

62 NKOMO, S.M. \& STEWART, M. (2006) "Diverse identities," in Clegg, S.A.; Nord, W.R. \& S. Hardy (eds.) Handbook of Organization Studies ( $2^{\text {nd }}$ ed.) Sage: New York.

63 PATON, C. (1998) "Prejudice in the corridors of power: A woman's work is still not done in parliament”, Sunday Times, 2 August: 19.

64 PILLAY, D. (1999) "Equity law is statutory change management," Business Day, 20 July: 4.

65 RAHIM, M.A. (2001) Managing Conflict in Organizations ( $3^{\text {rd }}$ ed.) Quorum Books: Westport, CT.

66 RAUTENBACH, F. (2005) "Indirect BEE through the JSE: Is South Africa making progress?”

Finance Week Report, 8 April: 1-37.

67 ROCCAS, S. \& BREWER, M.B. (2002) "Social identity complexity," Personality and Social Psychology Review, 6(2): 88-106.

68 ROTHMAN, J. (1997) Resolving Identitybased Conflict in Nations, Organisations, and Communities, Jossey-Bass: San Francisco.

69 ROWEN, P. (2000) "Black income to outstrip whites", Sunday Times, 18 March: 2.

70 SELBY, K. \& SUTHERLAND, M. (2006) "Space creation: A strategy for achieving employment equity at senior management level," South African Journal of Labour Relations, 30(2): 42-65.

71 SLABBERT, J.A. \& DE VILLIERS, A.S. (2003)

"The historical development of employee relations in South Africa," in Slabbert, J.A.; Swanepoel, B.J.; Backer, W. \& Prinsloo, J.J. (eds.) Managing Employment Relations in South Africa: 4.1-4.24. Juta: Johannesburg.

72 SMITH, P.B., PETERSON, M.F., \& SCHWARTZ, S.H. (2002) "Cultural values, sources of guidance, and their relevance to managerial behaviour," Journal of Cross Cultural Psychology, 33(2): 188208.

73 SIMON, B. \& KLANDERMANS, B. (2001)

Politicized collective identity: A social psychological analysis, American Psychologist, 56, 319-331.

74 SOUTH AFRICA (1995) Labour Relations Act. No 66 of 1995. Government Printer: Pretoria.

75 SOUTH AFRICA (1996) Constitution of the Republic of South Africa, Government Printer: Pretoria.

76 SOUTH AFRICA (1997) Basic Conditions of Employment Act. No. 75 of 1997, Government Printer: Pretoria.

77 SOUTH AFRICA (1998) Employment Equity Act. No. 55 of 1998, Government Printer: Pretoria. 
78 SOUTH AFRICA (1998) Skills Development Act. No. 97 of 1998, Government Printer: Pretoria.

79 SOUTH AFRICA (1998) Skills Development Levies Act. No. 9 of 1999, Government Printer: Pretoria.

80 SOUTH AFRICA (2001) Preferential Procurement Policy Framework Act, Government Printers: Pretoria.

81 SOUTH AFRICAN GOVERNMENT (2006) South African Government Website, http://www. safrica.info/women/womeninparliament (Accessed 8 December, 2006).

82 STATISTICS SOUTH AFRICA (2003) Census 2001. SSA: Pretoria.

83 SWANEPOEL, B.; ERASMUS, B; VAN WYK, M \& SCHENCK, H (eds.) (2003) South African Human Resources management: Theory and Practices ( $3^{\text {rd }}$ ed. revised) Juta: Johannesburg.

84 TAJFEL, H. \& TURNER, J.C. (1979) "An integrative theory of intergroup conflict," in Austin, W.G. \& Worchel, S. (eds.) The Social Psychology of Intergroup Relations: 33-47. Brooks/ Cole: Monterey, CA.

85 TERREBLANCHE, C. (2003) "Elite empowerment must be stopped," The Star, 6 June, http://www.thestar.co.za. (Accessed 18 January 2005).
86 THEUNISSEN, G. (2005) "Exacerbating a shortfall - Skills shortage: Economic trends and analysis," Finance Week, 14 March: 48-49.

87 THOMAS, A (2004) "Black economic empowerment: A study of South African companies", Management Today, May 2004: 35-38.

88 TURNER, J.C. \& GILES, H. (eds.) (1981) Intergroup Behavior, Blackwell: Oxford.

89 VAN GASS, C. (2005) "Report highlights South African's growing self-belief," Business Day, 17 May: 2.

90 VAN DER WESTHUIZEN, C. (1999) "VroueLP's se stryd nie maklik," Naweek-Beeld, 17 July: 4.

91 VAN ROOYEN, D. (2004) "Stormloop na swart bestuurslui kom,” City Press Rapport Loopbane, 17 April: 1.

92 VECCHIO, R.P. (2003) "In search of gender advantage," The Leadership Quarterly, 14: 835-850.

93 WASSERMAN, H. (2005) "Talking of change: Construction of social identities in South African media debates," Social Identities, 11(1): 75-85.

94 WRAY, Q. (2004, "Empowerment apathy rules at SA Inc." Business Report, 18 March: 21.

95 WRAY,Q., SIKHAKANE, J., MOKOPANELE, T. \& HAMLYN, M (2006) "Cabinet approved BEE codes are already drawing criticism," Business Report, 8 December 8: 2. 